\title{
The Nature of Country of Origin Effect: Exploring COO Effect on Arçelik A.S.
}

\author{
Volkan Öngel $^{\mathrm{a}}$, Elif Öngel ${ }^{\mathrm{b}}$ \\ ${ }^{a}$ Faculty of Economics and Management, Beykent University, Turkey \\ ${ }^{b}$ Business and Management, Manchester Metropolitan University, UK
}

\begin{abstract}
This paper examines the nature of the Country of Origin effect by exploring suggested options to enhance positive COO associations in consumers' minds and offsetting negative COO impact on purchase decisions. The approach taken is a literature review with a comparison of Turkey's white goods brand Beko Plc's international growth and marketing strategies. This paper focuses on suggested international marketing strategies in order to increase the country image of Turkey as well as the brand image of Beko Plc. In the interest of achieving a sustainable growth in foreign markets and offsetting the negative consumers' perceptions of products made in particular countries, organizations are in need of advanced quality management practices and applicable pricing policies that respond adequately to consumer needs.
\end{abstract}

Keywords: Country of Origin, Country Image, International Marketing

JEL Code: M31

(C) 2014 Published by SSBFNET

\section{Introduction}

The process of introducing a brand name to foreign markets is influenced by the target market behaviour and structure as well as competition with other local and global brands. Based on the situation, it might be necessary for organizations to communicate brand's story quickly in one marketplace or announce it in several markets at the same time (Rundh, 2003). Introducing a new brand name to foreign markets would raise potential problems that might hinder the desired outcome for organizational performance. In order to avoid a failed attempt, organizations are required to define the target audience and communicate the brand name through the appropriate channels.

As the existing literature suggests; 'increasingly competitive international marketplace of the late 1980's and early 1990's' (Hooley et al 1988); 'growth in international trade and development of global markets' (Al-Sulaiti and Baker, 1998) have caused an increasing interest on the changing characteristics of consumer behaviour as the perception of a country and/or brand name have a crucial impact on 'production evaluations' (Schaefer, 1997) as well as 'consumer decision making process' (Insch and Florek, 2008).

\footnotetext{
${ }^{a}$ Corresponding author.
} 
The purpose of this paper is to explain the country of origin effect while exploring the factors that allows creation of favourable associations of the product on consumer purchase process and consider the aspects to alienate the negative Country of Origin (COO) effect with the examples from Arçelik A.Ş. and its international representative brand; Beko Plc.

The first part of this paper outlines the general theoretical framework of the research. The nature of the country of origin effect by exploring suggested options to enhance positive $\mathrm{COO}$ associations in consumers' minds and offsetting negative $\mathrm{COO}$ impact on purchase decisions

\section{Theoretical Framework}

\subsection{Country of Origin Effect}

A country name, similar to a brand name, has a compelling impact on the individual's suppositions towards a product produced in a particular country as the evidence suggests that not only brand reputation but also country related information (Kim, 1995) affects the consumer's purchase decisions.

Although many definitions are available, COO effect, as Wang and Lamb (Al-Sulaiti and Baker, 1998; 150) suggested, is 'intangible barriers' that simply allows or hinders the entry to a new market. Phau and Suntrornnod (2006) also stated that the country of origin is a concept that includes crucial information that enables the products success in the world market, whereas it was stated by Johansson, et al., (Al-Sulaiti and Baker, 1998) and later by Ozsomer and Cavusgil (Al-Sulaiti and Baker, 1998), country of origin is the country where a brand is from.

On the other hand, many researchers agree on a different aspect of COO. As it was stated by Al-Sulaiti and Baker (1998; 150); .a product's country of origin is the country of manufacture or assembly. It refers to the final point of manufacture which can be the same as the headquarters for the company.

\subsection{Enhancing Positive Country of Origin Effect Associations}

Many marketing researchers indicate that the product appraisal (such as value, quality, workmanship etc.) is essentially affected by the consumer's knowledge of 'where the product was made' (D'Astous and Ahmed, 1999; 110).

However, the importance of made in... label is not necessarily the main element on the decision making process involved to purchase a product. As it was found in a multinational study that involves 2,200 participants, the COO effect was perceived to be less effective than the attributes of the product (D'Astous and Ahmed, 1999). Specifically the participants aged less than 35 reported that 'they did not care about COO' (D'Astous and Ahmed, 1999; 108) when they make purchase decision.

Although suggestions were made to explain this conflict better, many researchers agree that (D'Astous and Ahmed, 1999) consumers who are making purchase decision have the knowledge of COO without being aware of it, as COO can be communicated through many ways such as brand name (Thakor and Lavack, 2003) or brand origin. 
A great number of companies have used the positive associations of COO as an advantage in a competitive business environment (Kinra, 2006). Thus, it can be used either emphasising the COO as 'American jeans, Italian pasta' (Kinra, 2006), or favourable associations such as 'silk with China, cars with Germany, chocolate with Belgium.' Another way to communicate $\mathrm{COO}$ is to directly use $\mathrm{COO}$ in brand names such as 'Air France, Newcastle born Ale' (Thakor and Lavack, 2003). Based on Yavas and Tuncalp's (1984) study in Saudi-Arabia, it is possible to see the psychological effects of made in... label on consumers' preferences. Through their study, components evaluated the products which have made in UK label. The questionnaire shows the following results (Yavas and Tuncalp, 1984; 45).

Based on Yavas and Tuncalp's (1984) study in Saudi-Arabia, it is possible to see the psychological effects of made in... label on consumers' preferences. Through their study, components evaluated the products which have made in UK label. The questionnaire shows the following results (Yavas and Tuncalp, 1984; 45)

Table 1: Saudi Consumers' Attitudes Toward Made-in UK Label

\begin{tabular}{|c|c|c|c|}
\hline \multirow[t]{2}{*}{ Statement } & \multicolumn{3}{|c|}{ Percent } \\
\hline & Disagree & Neutral & Agree \\
\hline 1. Products manufactured/imported from UK are expensive & 4,5 & 11,4 & 84,1 \\
\hline 2. Products Manufactured/imported from UK are generally low quality & 69,3 & 13,6 & 17,1 \\
\hline 3. Products manufactured/imported from UK are good value for money & 39,8 & 12,5 & 47,7 \\
\hline $\begin{array}{l}\text { 4. Whenever available, I would prefer to buy products manufactured/imported from } \\
\text { UK }\end{array}$ & 17,0 & 26,1 & 56,9 \\
\hline $\begin{array}{l}\text { 5. Products manufactured/imported from UK would give me prestige and status } \\
\text { among my friends }\end{array}$ & 22,7 & 21,6 & 55,7 \\
\hline 6. Products manufactured/imported from UK have attractive style and appearance & 23,9 & 14,8 & 61,3 \\
\hline 7. Products manufactured/imported from UK are well known in Saudi Arabia & 15,9 & 14,8 & 69,3 \\
\hline 8. Products manufactured/imported from UK are widely available in Saudi Arabia & 21,6 & 19,3 & 59,1 \\
\hline $\begin{array}{l}\text { 9. Products manufactured/imported from UK provide sufficient repair and } \\
\text { maintenance services }\end{array}$ & 18,2 & 20,5 & 61,3 \\
\hline $\begin{array}{l}\text { 10. Products manufactured/imported from UK provide satisfactory warrantees and } \\
\text { guarantees }\end{array}$ & 25,0 & 26,1 & 48,9 \\
\hline $\begin{array}{l}\text { 11. Products manufactured/imported from UK are well suited to the needs of Saudi } \\
\text { consumers }\end{array}$ & 20,5 & 30,7 & 48,8 \\
\hline $\begin{array}{l}\text { 12. After considering the factors listed previously, I consider UK as an ideal country } \\
\text { as a manufacturer/exporter of products. }\end{array}$ & 20,5 & 27,3 & 52,2 \\
\hline
\end{tabular}

Source: Yavas and Tuncalp, 1984; 45 
As the table.1 shows, respondents of the survey were in conflict towards products provided by UK manufacturers as most of them were pleased by the guarantees and in terms of providing repair and maintenance services, but on the other hand, $84.1 \%$ of the participants agreed that products imported from UK are expensive whereas $39.8 \%$ of them agreed that goods from UK are not good value for money.

When we consider the fact that UK's competitors in Saudi Arabia's market such as USA, Germany and Japan are favored to be less pricy and relative to quality, UK manufacturers, as Yavas and Tuncalp $(1984 ; 43)$ stated, 'need to bring their prices in line with competitors' in order to build favourable associations between the products and consumers. With a better pricing policy, UK manufacturers could gain advantage.

It is known to international marketing researchers that consumers' willingness to pay more for products when it is produced in a desirable country (Clarke III, et al., 2000) can be directly used an advantage in one organization's global marketing strategy as $\mathrm{COO}$ affect has the direct impact on the success of products in global markets (Clarke III, et al., 2000).

\subsection{Traditional View of $\mathrm{COO}$ in Some Countries vs. Recent View}

Ever since the middle of the last century, Asian countries have become the home of cheap labour which eventually created a big interest for western manufacturers and 'contributed to building post-colonial economies' (Parkvithee and Miranda, 2012). As a result of that, western brands, even though they were produced in Asian countries itself, dominated the Asian markets (Parkvithee and Miranda, 2012).

In addition to that, it is possible to see indications that show the consumer preferences for western brands in Asian countries. For instance, a study by D'Astous and Ahmed (Parkvithee and Miranda, 2012; 8) showed that 'Thai respondents are less favourable towards products made in newly industrializing South Asian countries.'

On the other hand, the traditional assumptions for Chinese consumers suggest that they 'had a strong preference for foreign brands' (Kowk et al., 2006; 164). This was supported by the constant foreign brand entries to the Chinese market (Kowk et al., 2006). The main reason for western originated brand preference was the assumption of foreign brands, as Chinese consumers 'traditionally associated foreign brands with concept of sophistication, prestige, modernity and novelty’ (Kowk et al. 2006; 164).

Yet the competitive business environment and growing international markets are forcing local brands to improve their product quality as the governments are now more protective towards a more refined market place (Kwok et al., 2006). As a result of that, studies have started to show that foreign brands are no longer priority to preference (Kwok et al 2006). Especially 'Chinese consumers, in general, prefer local products over comparable foreign goods.' (Kwok et al., 2006; 164).

Also recent evidence shows that 'more advanced nations like China, India, Singapore, Hong Kong, Thailand, and Malaysia have also begun to develop their own global brands.' (Parkvithee and Miranda, 2012; 7-8). Thus the rapid 
growth of Chinese brands is not only becoming favored within China but is also becoming a 'global phenomenon.' (Kwok et al, 2006; 164).

On the other hand, a study in Uzbekistan showed that, Uzbeks consider COO information more significantly in the event of buying more advanced and expensive products. Study also suggests that products such as cars, cameras, televisions, refrigerators which were made in Japan is 'perceived to be higher quality than those made in other countries.' (Zain and Yasin, 1997; 142). According to the list, goods produced in USA placed on second where Russia was the following country. Products from less developed countries such as India and Uzbekistan itself were considered to be low quality. (Zain and Yasin, 1997).

This perception is also yet to change. Based on the recent evidence, there is a positive relationship between product evaluation and degree of economic development of the sourcing country. (Zain and Yasin, 1997).

\subsection{County Image of Turkey}

The Country of Origin effect directly benefits from the country's image (Keller, 1993), thus improving country image will allow improvements on the consumers' perception of 'strengths and weaknesses' (Zamantili Nayir and Durmusoglu, 2008; 792) of particular country. The current literature suggests the COO effect can influence quality assumptions of a particular products rather than the price and brand information. In order to create a strong country image and increase the favourable quality and reliability associations in the consumers' minds, developments in many aspects are needed especially for newly industrialized countries.

Turkey has managed to do compelling changes 'in its democratic regulations, economic structures, and political systems' (Zamantili Nayir and Durmusoglu, 2008; 793) in order to become a member of the European Union. Although many negative issues still ongoing in Turkey (heavy-handed government [BBC, 2014]), as Zamantili Nayir and Durmusoglu (2008; 794) stated; the impact of 'harmonization packages' of the European Union on modernization, capability for political decision-making, trade unions but more significantly in terms of economic development level enabled Turkey to be referred as a part of the 'MINT Countries: Next Economic Giants' (BBC, 2014).

Despite the geographical importance of Turkey and its potential to develop globally, 'the awareness of Turkey's history and its contributions to the modern world still runs low.' (Sevin and Salcigil White, 2011; 86). Possible membership with the European Union will help increase the country's image with more opportunities for foreign direct investments as well as import/export activities which will yield in sustainable economic growth and will cause better COO effect for Turkish products (Zamantili Nayir and Durmusoglu, 2008). Also, based on the expected growth of the MINT countries (Mexico, Indonesia, Nigeria, and Turkey), possible growth of the economy will enable favourable associations for products with made in Turkey label as the expected growth is shown table.2 (BBC, 2014); 


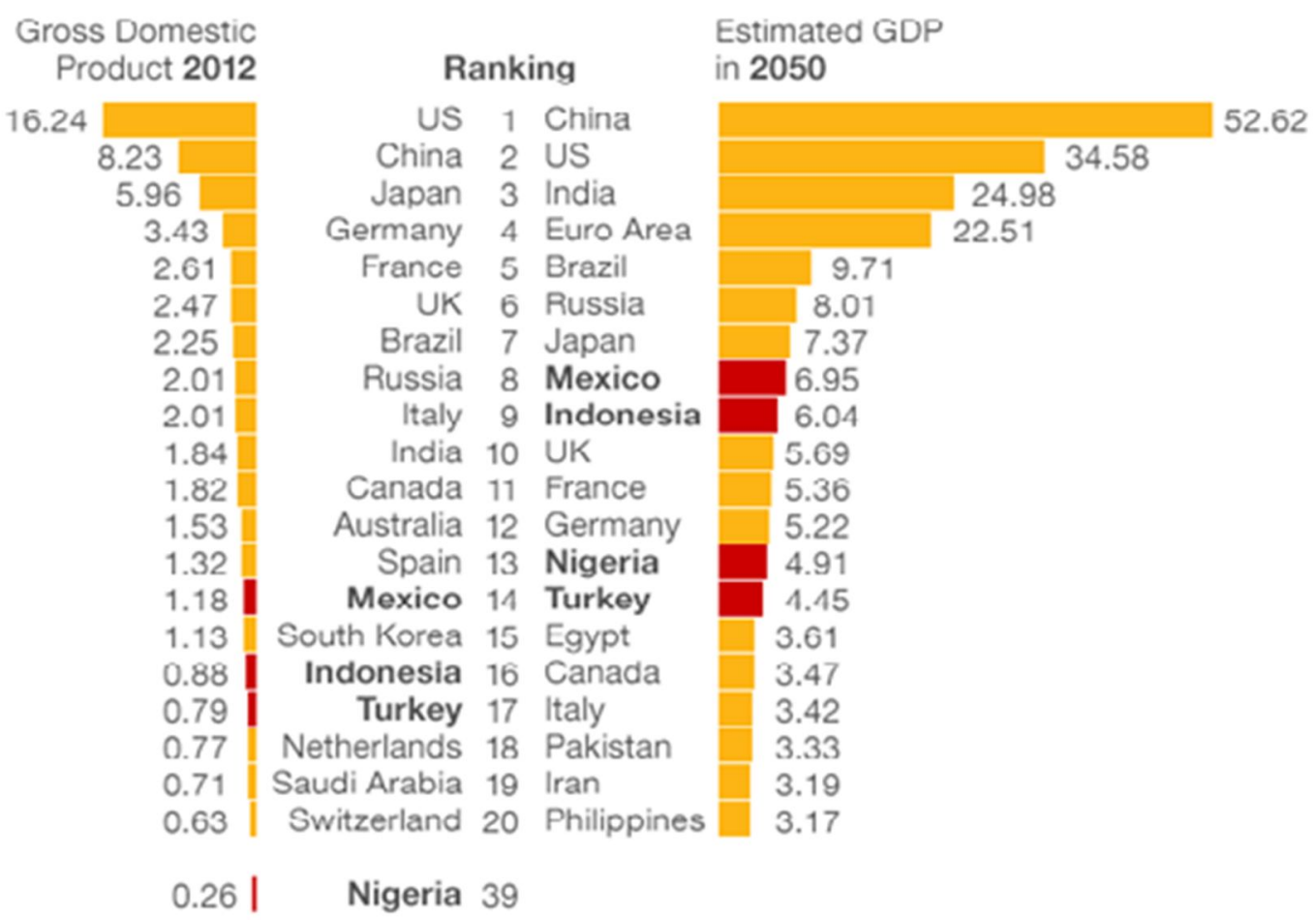

Source: BBC, 2014

Figure 1: Rise of MINT's (\$ Trillions)

Although Turkey's candidacy in European Union and remarkable economic growth in the last 20 years has caused increased attention, it is already possible to see the name of some leading Turkish brands in global markets. As some Turkish brands are establishing their brand name to become global such as Turkish Airlines or Beko Plc; others such as Ulker acquired high profile Godiva chocolate brand to enter new market while trying to minimise possible negative country of origin effect (Demirbag, et al., 2010).

\section{Arcelik A.S. and Its International Representative: Beko Plc.}

Beko Plc. is subsidiary of Arcelik A.S. (incorporated company) established in 1955. Both of the companies are part of a large multinational group called Koc Holding which is Turkey's biggest industrial and commercial conglomerate and one of the top 500 large companies in the world (Beko, 2014).

While Arcelik A.S. is manufacturing its home appliances and dominating not only domestic market but also global markets, Koc Holding's strategic plan was to expand the company brand to European markets with the name of Beko Plc (Capital, 2003).

Beko Plc, which entered to UK markets 'with commercial refrigerators in 1991' (The Republic of Turkey Prime Ministry, 2011), managed to become 'UK's leading, and best-selling home appliance manufacturer' (PR News Wire, 2014) in their $21^{\text {st }}$ year. 
When London, beside New York as a centre for global finance, was effected by the global financial crisis (Council of Foreign Relations, 2009), the deep recession of the economy affected many industries and businesses in Britain. The increased unemployment rate, GDP revising down to $0.3 \%$, sudden unpleasant increase on inflation to $3 \%$, the cut on interest rates down to $0.5 \%$ (The Guardian, 2010) had impact on the consumers' decision making process.

Besides this, the changing characteristics of Western European markets in late 1980's and the rising prices in Eastern European countries gave Beko Plc. the opportunity to move into the UK's markets in order to meet the demand for 'table-top refrigerators' (Gulsoy, et al., 2013; 18). Another reason why Beko chose the UK market to start expanding was the fact that it was 'price sensitive and not dominated by domestic brands.' (Gulsoy, et al., 2013; 18).

During that formidable time, Beko Plc. was providing a wide range of house appliances that were developed as nature friendly with less energy consumption and lower pricing (Arçelik A.Ş. Annual Report of 2012) than that of their competitors to the UK consumers.

For a company such as Koc Holding, Arcelik A.S.'s operations in the domestic market were not fulfilling enough as they were seeking opportunities to continue their internationalization. When export activities started with the neighbouring countries, exporting ultimately become the main factor in growing strategy (Goldstein, et al., 2006). When Turkey 'agreed a schedule of phased tariff reductions with the European community in 1988' (Goldstein, et al., 2006; 15), Arcelik A.S. signed an OEM (Original Equipment Manufacturer) contract in United States. After starting to supply refrigerators under the name of Kenmore, nine years later, Arcelik A.S. had negotiated a deal with 'European Whirlpool for dishwaters' (Goldstein, at al., 2006; 16). As a result of that, Arcelik A.S. 'was committed not to sell similar products in Europe under own brands.' (Goldstein, 2006; 16).

As exporting had become the core element for internalization of the company, and Arcelik was tied down with contracts. They needed different strategic options to continue their internalization. For that matter, Arcelik A.S. acquired Beko white goods and TV sets and entered UK markets which later 'extended to France, Germany and Spain' (Goldstein, et al., 2006; 16). Arcelik A.S. had to follow different strategical business plans for the entry of the new markets as they had many competitors in Europe. Such competitors with strong brand names were already operating in those countries for years and had already built up an established customer base, Arçelik A.Ş had to build such a 'hardwon relationship' which could have hindered the process (Bonaglia and Goldstein, 2007).

As Onkvisit and Shaw (Gulsoy, et al., 2011; 1210) stated that a company can do exporting to foreign markets with three different channels;

- 'Branding or no branding'

- 'Creating vs acquiring'

- 'Single vs multiple brands'

Working for OEM and manufacturing refrigerators and then dishwashers for a leading brand helped Arçelik A.Ş. to learn the how's of the business environment; how to manufacture, how to fit in the system and how to build high 
quality products etc (Gulsoy, et al., 2011) . Learning how to serve the brand enabled Arçelik A.Ş. to 'gain access to advanced production skills, which consequently led to the improvement of product quality and service.' (Gulsoy, et al., 2011; 1210). Although they were existing in the market through manufacturing other brands, establishing their own brand was their main objective, so they had to go through the branding of Beko.

In 2000s, Arçelik A.Ş. was making agreements with strong brands such as Korea's LG in 1999, and was getting financial support from the 'International Finance Corporation (IFC), and the private sector arm of the World Bank Group' (Bonaglia and Goldstein, 2007; 22) that allowed Arçelik A.Ş. to widen their product range.

At the beginning of 2000s, Arçelik A.Ş. and Beko Plc. adopted a new logo that was designed by an American corporate graphic studio. The purpose was to create the image of a new, fresh player in a global market that is dominated by western brands as well as giving the signs of transformation of change (Goldstein, et al., 2006).

Milestones of Arçelik A.Ş, as it is stated by Bonaglia and Goldstein (2007; 23) follows:

Table 3: Arçelik A.Ş. Milestones

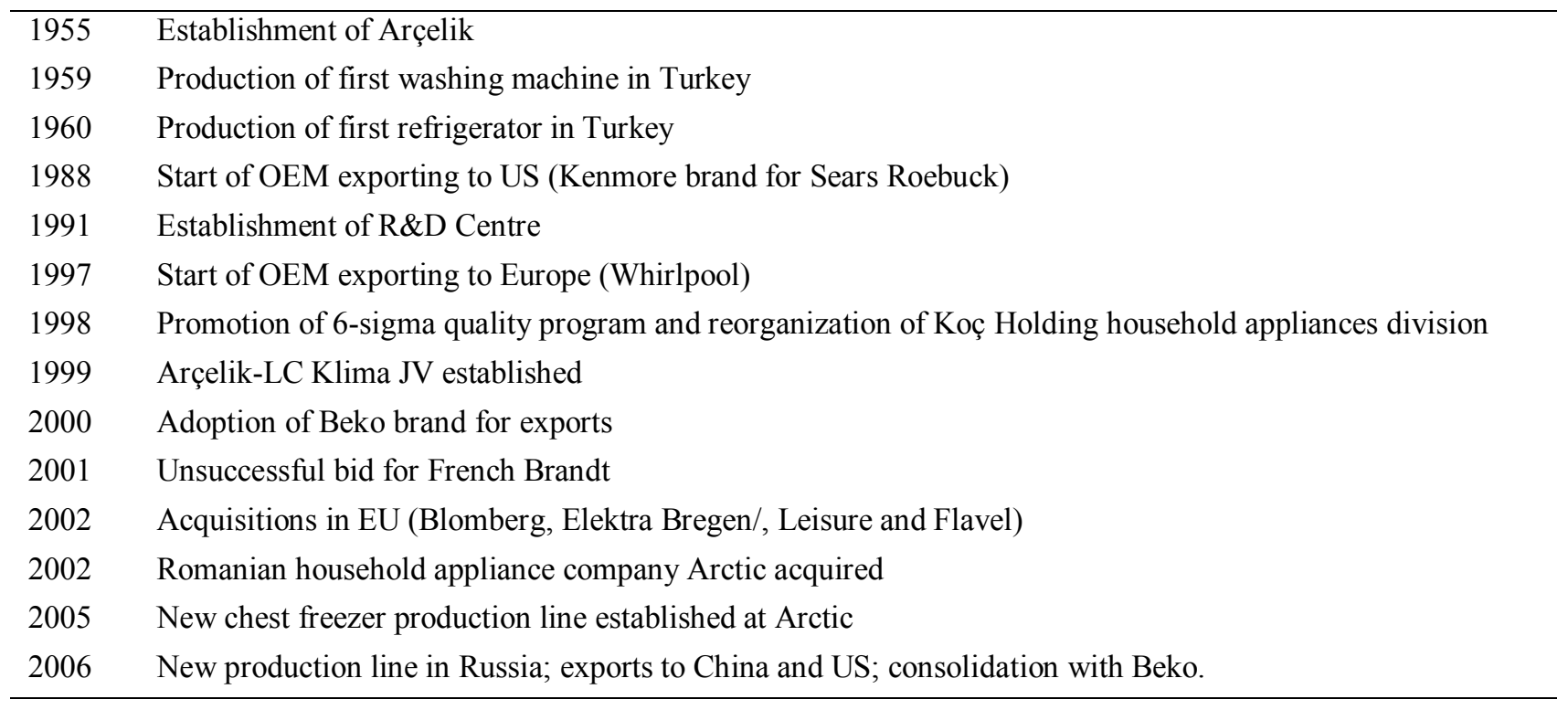

Within five years of globalisation being initiated, production was established in six countries. Foreign sales accounted for 44 per cent of total sales. Brands: Arçelik, Beko, Blomberg, Elektrabregenz, Arctic, Leisure, Flavel, Altus

(Bonaglia and Goldstein 2007; 23)

Beko Plc.'s product range that focuses on 'intelligent solutions' (Arçelik A.Ş. Annual report of 2012) and the company's focus on innovation, allowed them to compete with established brands in global markets. The emphasis on Research and Development department allowed Arçelik A.Ş. to become $95^{\text {th }}$ and only Turkish company on PCT's (Patent Cooperation Treaty) list in 2010 (WIPO, 2011) on a global scale. 
Innovation and smart solutions to family concepts helped Beko Plc to increase the 'value of its brand positioning, and strengthened consumer awareness about Beko and its products when compared to the years before.' (Arçelik A.Ş. annual report, 2012; 30). As the numbers showed the success of the firm on their annual report (Koc Holding Annual Report, 2013; 72);

\section{Table 4. Arçelik A.Ş. International Position}

$3^{\text {rd }}$ largest company in Europe in the sector

Clear market leader in Romania and South Africa with its Arctic and Defy brands, respectively

Arçelik's international white goods brand Beko was

- $3^{\text {rd }}$ largest in European white goods market and $2^{\text {nd }}$ in the freestanding white goods market

- $2^{\text {nd }}$ in Western Europe white goods market Best-selling refrigerator brand in Western Europe

- White goods market leader in the UK and Lithuania

- Among the top three white goods market brands in France and Poland

Koc Holding Annual Report, 2013

The growth of Beko Plc. in UK market was remarkable. Çeviköz (2012) stated that; . We are proud of the fact that one in every six electrical household appliances in Europe bears the seal of 'Made in Turkey'. Actually, BEKO has become the largest company for refrigerators and cooking appliances in the UK market..

The global existence of developing countries, changing circumstances of the markets and business environments, WTO's (World Trade Organization) free trade operations, and more importantly globalization caused many organizations to build global brands.

The process of introducing a brand name to foreign markets is influenced by the target market behaviour and structure as well as competition with other local and global brands. Based on the situation, it might be necessary for organizations to communicate brand's story quickly in one marketplace or announce it in several markets at the same time. (Rundh, 2003).

Introducing a new brand name to foreign markets would raise potential problems that might hinder the desired outcome for organizational performance. In order to avoid a failed attempt, organizations are required to define the target audience and communicate the brand name through the appropriate channels.

Tufekci (Marketing Manager of Arçelik A.Ş.) stated in one of his interviews that despite the big difference on population between Turkey and the UK, refrigerator sales turn out to be similar. The reason for this close result is, while 1.7 persons per household living in the UK, this ratio is 4.8 in Turkey because of the crowded family structure (SAU, 2011). As many people living in big cities tend to live in small apartments, Arçelik A.Ş.' target audience in different markets is also changing with their product range in order to offer smart solutions to different needs.

Another issue raised by the entry to a new market is the $\mathrm{COO}$ effect and the alleged difference on consumer behaviour. In order to minimise the negative effect of made in Turkey label, Arçelik A.Ş. followed different strategies in different 
countries. For instance, while they aim to build a brand name with Beko Plc in UK, Arçelik A.Ş. decided not to change German Grundig's name when two company merged.

Arçelik A.Ş. was also disappointed when they first attempted to introduce Beko Plc. to the French markets. French furniture chain Conforama rejected to display Turkish product on the shelves. .Beko's head of marketing in France revealed that the firm had been manufacturing Conforama's respected in-house brand for years (Czinkota, 2014).

It was then that Beko Plc machines started to become a big player in the French market.

One of the challenges of entering a new market shows itself when an organization moves into a new language system. Building brand loyalty and awareness is linked to the name of the brand as it could make it easier for consumers to accept and remember the brand name easily, or it could hinder the progress of acceptance. Although the problem seems to be between western languages and Eastern Asian languages (Steenkamp, 2014), the phonemes specific to Turkish language would have made is harder for European consumers to embrace the brand name as Arçelik A.Ş.'s name is unfamiliar with any European language.

\section{Offsetting Negative Country of Origin Effects in the Case of Beko Plc.}

Factors such as constant change in global markets, globalization and competition had a significant impact on developing economies. Although the business environment is developing through the use of information and technology, there are many perils of the changing circumstances. As many local brands started to play a role in global markets, free trade also enabled industrialized country brands to dominate the markets on a global scale.

In order to adapt and compete with these changes, it is necessary for newly industrializing countries to implement international strategies based on the quality as quality of the product is the key element for surviving through competitiveness (Madu, 1997). Considering the changing characteristics of consumer's behaviour, as they are now 'more aware and more careful in selecting products' (Madu, 1997; 283), brands from developing countries should try to establish their names through quality rather than being a cheap alternative, thus creating favourable associations with quality and, in turn, the product improves the country image. Particularly in white goods and house appliances industry, providing reliable and durable products has a crucial importance.

According to latest news regarding Beko Plc., their faulty products is damaging the reputation of the brand. Likewise, the misleading information on Beko Plc's website caused the loss of potential customers in the UK. Although Beko Plc took action to contact retailer and consumers directly to fix the problem (BBC, 2011), 'around 138,000 affected products remain in UK homes.' (Choi, 2013).

In order to increase brand loyalty and enhance positive associations with the brand in the consumer's mind, brands from newly industrialized countries are suggested to put emphasis on quality as 'quality is becoming universally important' (Gosen, et al., 2005; 453).

Nart's study (2008) showed that the products on international markets are perceived to be unfamiliar presentations by consumers. Rather than making rational decisions, it is expected from them to use cue factors to make purchase 
decisions. As a result of that supposition of a particular country and country of origin evaluations are considered to be directly linked to brand perceptions.

Further to his research, the questionnaire results (Nart, 2008) found that UK consumers associating German brand Bosch more favourable than the Turkish Beko. The negative perception of Turkey appears to be a barrier for the success of Beko in UK markets. In other words, international success depends on international marketing strategies where Beko cannot benefit from the country name as much as Bosch benefits from the German name.

\section{Conclusions}

Internalization of the markets and globalization are the two main factors that encourage organizations to grow globally. In order to achieve sustainable growth and success in foreign markets, companies are compelled to develop with international marketing strategies to ease the entry to the market and help them strengthen their position. International marketing strategy is crucially important as the organization needs to improve country image and offset negative suppositions towards the country as well as introducing a completely unfamiliar brand name to a foreign market.

In the case of Beko Plc, they are recommended to determine the target audience, therefore;

Determine the price range: Although the current economic circumstances of the UK allows consumers to prefer lower priced products, the danger with low priced products is to create the supposition of low price equals to low quality. Thus, Beko Plc. is recommended to focus the quality management process and offset the low quality product presumptions.

Determine the product range and adapt product development according to consumer preferences: As there is a difference on family structure between the origin country of Beko and the country where they want to operate, they are recommended to consider the fact that the needs of the families are also different. As the human to house is larger in Turkey, for instance, consumers are usually looking for larger capacity washing machines, whereas in the UK, consumers are more willing to buy washing machines with a built-in dryer feature.

Promotion: In order to minimise the negative effects of Country of Origin label, Beko Plc. is recommended to promote their innovative products in foreign markets. In favor of different promotional strategies such as advertising through different channels, sales promotions, Arçelik A.Ş ought to pay attention to public relations. 


\section{References}

Arcelik A.S. (2012) Annual Report [Online] [Accessed on 18 ${ }^{\text {th }}$ of April 2014] http://www.arcelikas.com/UserFiles/file/2012ARN.pdf

Al-Sulaiti, K. I., and Baker, M. J. (1998) Country of Origin Effects: A Literature Review. Marketing Intelligence \& Planning vol. 16(3) pp.150-199

BBC (2011) Beko Fridge Fire Fault: Police Inquiry into Man's Death [Online] [Accessed on 22 ${ }^{\text {nd }}$ of 2014] http://www.bbc.co.uk/news/uk-england-london-14076607

BBC (2014) The Mint Countries: New Economic Giants? [Online] [Accessed on 10 $0^{\text {th }}$ of April, 2014] http://www.bbc.com/news/magazine-25548060

Beko (2014) [Online] [Accessed on $18^{\text {th }}$ of April 2014] http://www.beko.co.uk/Pg/AboutBeko

Bonaglia, F. and Goldstein, A. (2007) .Strengthening Productive Capacities in Emerging Economies through Internationalisation: Evidence from the Appliance Industry. [Online] [Accessed on 19 $9^{\text {th }}$ of April 2014] http://www.oecd.org/dev/39147683.pdf

Capital (2003) .Making a Difference Widens the Gap. [Online] [Accessed on 18 ${ }^{\text {th }}$ of April, 2014] http://www.capital.com.tr/fark-yaratan-arayi-aciyor-haberler/15556.aspx

Cevikoz, U. (2012) Keynote address of Ambassador Unal Cevikoz at the .Turkey's Promotion Day. [Online] [Accessed on $18^{\text {th }}$ of April, 2014] http://london.emb.mfa.gov.tr/ShowSpeech.aspx?ID=2185

Choi, C. (2013) .Nearly 138,000 Beko Products Could Be a Safety Risk in UK Homes. ITV [Online] [Accessed $22^{\text {nd }}$ of April 2014] http://www.itv.com/news/2013-03-01/nearly-138-000-beko-products-a-safety-risk-in-uk-homes/

Clarke III, I., Owens, M. and Ford, J.B. (2000) .Integrating Country of Origin into Global Marketing Strategy. International Marketing Review vol. 17(2) pp.114-126

Council of Foreign Relations (2009) Issue Guide: Britain and the Global Financial Crisis [Online] [Accessed on $18^{\text {th }}$ of April, 2014] http://www.cfr.org/world/issue-guide-britain-global-financial-crisis/p19516

Czinkota, M. (2014) Managing Country of Origin Perceptions/International Marketing 10th [Online] [Accessed on $25^{\text {th }} \quad$ April 2014] http://michaelczinkota.com/2014/04/managing-country-of-origin-perceptions-internationalmarketing-10th/

D'Astous, A. and Ahmed, A. S. (1999) .The Importance of Country Images in the Formation of Consumer Product Perceptions. International Marketing Review vol. 16(2) pp. 108-125

Demirbag, M., Sahadev, S. and Mellahi, K. (2010) .Country Image and Consumer Preference for Emerging Economy Products: the Moderating Role of Consumer Materialism. International Marketing Review vol. 27(2) pp.141-163

Goldstein, A., Bonaglia, F. and Mathews, J. (2006) .Accelerated Internationalization by Emerging Multinationals: The Case of White Goods. [Online] [Accessed on $19^{\text {th }}$ April 2014] http://www.oecd.org/development/pgd/36317032.pdf Gulsoy, T., Ozkanl1, O. and Lynch, R. (2011) .International Branding Strategies of Developing Countries: The Case of Arcelik. $7^{\text {th }}$ International Strategic Management Conference 1201- 1217

Gulsoy, T., Ozkanl1, O. and Lynch, R. (2013) .Effective International Expansion Strategies of Emerging Countries: the Strategies that Helped Arcelik. Management Research Review vol. 36(1) 4-32 
Gosen, J., Babbar, S., and Prasad, S. (2005) .Quality and Developing Countries: the Role of International and Organizational Factors. International Journal of Quality \& Reliability Management vol. 22(5) pp.452-464

Hooley, G., Shipley, D., and Kriger, N. (1988) .A Method for Modelling Consumer Perceptions of Country of Origin. International Marketing Review vol. 5(3) pp.67-76

Insch, A. and Florek, M. (2008) .Prevalence of Country of Origin Associations on the Supermarket Shelf. International Journal of Retail \& Distribution Management vol. 37(5) pp. 453-471

Keller, K. L, (1993) .Conceptualizing, Measuring, and Managing Customer-Based Brand Equity. Journal of Marketing vol. 57/January pp. 1-22

Kim, C. K. (1995) .Brand Popularity and Country Image in Global Competition: Managerial Implications. Journal of Product \& Brand Management vol. 4(5) pp. 21-33

Kinra, N. (2006) .The Effect of Country-of-Origin on Foreign Brand Names in the Indian Market. Marketing Intelligence \& Planning vol.24 (1) pp.15-30

Koc Holding Annual Report (2013) [Online] [Accessed on 22 ${ }^{\text {nd }}$ of April 2014] http://www.koc.com.tr/en-us/investorrelations/financial-statements-andstatistics/Annual\%20Reports/KOC\%20HOLDING\%20ANNUAL\%20REPORT\%202013.pdf

Kwok, S., Uncles, M. and Huang, Y. (2006) .Brand Preferences and Brand Choices among Urban Chinese Consumers: An Investigation of Country-of-Origin Effects. Asia Pacific Journal of Marketing and Logistics vol. 18(3) pp. 163-172 Madu, C. N. (1997) .Quality Management in Developing Economies. International Journal of Quality Science vol. 2(4) pp. 272-291

Nart, S. (2008) .The Reflections of Country-of-Origin Effect on Consumers' Perceptions and Behavioural Intension: A Comparative Study in UK Market. Suleyman Demirel University the Journal of Faculty of Economics and Administrative Sciences vol. 13(3) pp. 153-177

Parkvithee, N. and Miranda, M. J. (2012) .The Interaction Effect of Country-of-Origin, Brand Equity and Purchase Involvement on Consumer Purchase Intentions of Clothing Labels. Asia Pacific Journal of Marketing and Logistics vol. 24(1) pp. 7-22

Phau, I. and Suntrornnod, V. (2006) .Dimensions of Consumer Knowledge and Its Impacts on Country of Origin Effects among Australian Consumers: A Case of Fast-Consuming Product. Journal of Consumer Marketing vol. 23(1) pp.34-42

PR News Wire (2014) .FA Cup Partner Beko Launches New National Keepy-uppy Challenge in Bournemouth. [Online] [Accessed on $14^{\text {th }}$ of April, 2014] http://www.prnewswire.com/news-releases/fa-cup-partner-beko-launchesnew-national-keepy-uppy-challenge-in-bournemouth-241603371.html

Rundh, B. (2003) .Rethinking the International Marketing Strategy: New Dimensions in a Competitive Market. Marketing Intelligence and Planning vol. 21(4) pp.249-257

SAU (Sakarya University) (2011) Arcelik Marketing Manager Told Marketing Strategies [Online] [Accessed on $25^{\text {th }}$ April 2014] http://www.haber.sakarya.edu.tr/etkinlik/arcelik-yoneticisi-sau\%E2\%80\%99de-pazarlama-stratejilerinianlatti/ 
Schaefer, A. (1997) .Consumer Knowledge and Country of Origin Effects. European Journal of Marketing vol. 31(1) pp. $56-72$

Sevin, E. and Salcıgil White, G. (2011) .Turkayfe.org: share your Türksperiance. Journal of Place Management and Development vol. 4(1) pp.80-92

Steenkamp, J.B. (2014) .How Global Brands Create Firm Value: the 4V Model. International Marketing Review vol. 31(1) pp.5-29

Thakor, M.V. and Lavack, A.M. (2003) .Effect of Perceived Brand Origin Associations on Consumer Perception of Quality. Journal of Product \& Brand Management vol. 12(6) pp. 394-407

The Guardian (2010) .The Road to Recession ... And Recovery. [Online] [Accessed on 18 $8^{\text {th }}$ of April, 2014] http://www.theguardian.com/business/interactive/2009/jan/22/recession

The Republic of Turkey Prime Ministry Investment Support and Promotion Agency, 2011 [Online] [Accessed on $18^{\text {th }}$ of April, 2014] http://www.invest.gov.tr/en-US/infocenter/news/Pages/080411-beko-market-leader-britain-whitegoods.aspx

WIPO (World Intellectual Property Organization) (2011) International Patent Filings Recover in 2010 [Online] [Accessed on 22 $2^{\text {nd }}$ of April 2014] http://www.wipo.int/pressroom/en/articles/2011/article_0004.html

Yavas, U. and Tuncalp, S. (1984) .Exporting to Saudi-Arabia: the Power of the Made-In Label. International Marketing Review Autumn/Winter pp. 40-46

Zain, O.M. and Yasin, N.M. (1997) .The importance of Country-Of-Origin Information and Perceived Product Quality of Uzbekistan. International Journal of Retail \& Distribution Management vol. 25(4) pp. 138-145

Zamantili Nayir, D. and Durmusoglu, S. S. (2008) .Country Image in the Context of European Union Membership: the Turkish Case. Journal of Management Development vol. 27(7) pp.791-808 